\title{
Trends in Federal Revenues: 1955-86
}

\author{
KEITH M. CARLSON
}

HE Reagan administration has proposed some major changes in the federal tax structure as part of its economic plan for the early $1980 \mathrm{~s}^{1}{ }^{1}$ Included in the proposal are cuts in individual income taxes and an increase in business depreciation allowances retroactive to January 1, 1981. These tax reductions are intended to increase productivity by increasing the incentives to save, work and invest in capital equipment. ${ }^{2}$

This article discusses the effect of these tax cuts on federal revenues. Because the exact form that the tax legislation will take depends on the actions of Congress, the focus of this article is on the effects of the original proposal as presented in March 1981. By way of background, trends in revenues for the last 25 years are summarized and discussed. This period is chosen for historical reference for two reasons: (1) it is long enough to encompass sufficient economic experience so that trends in the federal revenue structure are clearly discernible, and (2) by starting in 1955, it avoids the effects of distortions of the tax structure resulting from World War II and the Korean War. ${ }^{3}$ Although this period includes the Cold War of the $1950 \mathrm{~s}$ and the Vietnam War of the late $1960 \mathrm{~s}$, it primarily reflects peacetime conditions in the U.S. economy.

The changing nature of the federal revenue system is analyzed in terms of receipts as a percent of GNP,

\footnotetext{
1Executive Office of the President and Office of Management and Budget, Fiscal Year 1982 Buclget Revisions (March 1981). On June 4,1981 , the administration modifed the original proposal.

2For further discussion, see Laurence H. Meyer, ed., The Supply Side Effects of Economic Policy (Center for the Study of American Business and the Federal Reserve Bank of St. Louis, 1981).

${ }^{3}$ For a perspective that includes the $1930 \mathrm{~s}$ and $1940 \mathrm{~s}$, see Donald W. Kiefer, "The Automatic Stabilization Effects of the Federal Tax Structure," in The Business Cycle and Public Policy, 1929-80, A Compendium of Papers submitted to the Joint Economic Committee, Congress of the United States (GPO, November 28, 1980), pp. 172-208.
}

and the component taxes as a percent of total receipts. GNP provides a useful reference point because discussions of the role of government focus on expenditure and revenue trends relative to growth in the economy. An examination of component taxes relative to total receipts yields information relating to the elasticity of the tax structure, that is, the responsiveness of the tax system to economic growth, and the incidence of the tax system, that is, who pays the taxes.

Tax revenues are determined by two factors: the relevant revenue base and tax rates. Revenue trends, as shown in charts 1 and 2 , thus reflect both changes in the revenue base and legislation affecting the effective tax rate. Tables 1 and 2 summarize major tax legislation over the past 25 years.

\section{PAST TRENDS IN FEDERAL PEVENUES: $1955-80$}

From 1955 through 1961, revenues due to tax legislation changed very little (see table 1). The only component of federal revenues that reflected changes in tax rates during this period was social insurance contributions, and these changes were quite small (table 2). Otherwise, the composition of tax revenues changed as a consequence of the differential response of relevant tax bases to movements of the overall economy, as well as the sensitivity of each tax to changes in its base.

\footnotetext{
${ }^{4}$ A more complete analysis of the role of government and its impact on the economy would stress the amount of resources absorbed by way of expenditure. The financing of expenditure includes taxes, borrowing and money creation. The latter is, of course, a hidden tax, but is just as real as an explicit tax in terms of transferring resources from the private sector to the government. For a general discussion of the inflation tax, see Canl S. Shoup, Public Finance (Aldine Publishing Conpany, 1969), pp. 452-61.

5The incidence of a tax, that is, who bears the final burden of the tax, is, of course, much more complex than indicated here. Nonetheless, extending such an analysis for a tax system requires information on the types of taxes and their relative importance. For further discussion, see Shoup, Public Finance.
} 
Table 1

Major Revenue Actions: 1954-80

\begin{tabular}{|c|c|c|c|}
\hline Action & onate & $\begin{array}{l}\text { Revenue } \\
\text { effect, } \\
\text { oflilons }\end{array}$ & Nature of action \\
\hline Excise Tax Reduction & March 1954 & $5-10$ & $\begin{array}{l}\text { Dismanted Korean War excise tax structure, All excise } \\
\text { tax rates in excess of } 10 \text { percent were reduced to } 10 \\
\text { percent, except for } 20 \text { percent cabaret tax }\end{array}$ \\
\hline Internal Revenue code & August 1954 & 14 & $\begin{array}{l}\text { Complete revision of hiternal Bevenue code of } 1939 \\
\text { Included provisions for dividend credit and exclusion } \\
\text { retirenent income credit, and accelerated depreciafion } \\
\text { changes n tax laws since } 1954 \text { have been enacted as } \\
\text { amendments to this code }\end{array}$ \\
\hline Federal Ald Highway Act & June 1956 & 25 & 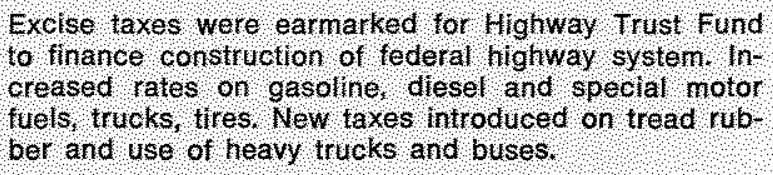 \\
\hline Revision of Deprectation & JuY 1962 & $\bullet$ & $\begin{array}{l}\text { Increased rate af which busnesses could wrie off plant } \\
\text { and equpment, Lives of machinent } \text { nade } 32 \text { percent } \\
\text { shorter }\end{array}$ \\
\hline Revenue Act of 1962 & oetober 1962 & 0,2 & $\begin{array}{l}\text { Provided investment lax credil of } 7 \text { percent on new and } \\
\text { used propery other than buldings }\end{array}$ \\
\hline Revenue Aot of 1964 & February 1964 & 114 & $\begin{array}{l}\text { Provided for wo-stage out in personal income, tax lia } \\
\text { bilites and corporate profts tax liabilites in } 1964 \text { and } \\
1965 .\end{array}$ \\
\hline Excise Tax Reduction & June 1965 & 47 & $\begin{array}{l}\text { Repealed excise taxes on several items and provided } \\
\text { tor systematic reductions in the rates on transpotation } \\
\text { equipment and communication services, }\end{array}$ \\
\hline Tax Adjustment Act of 1966 & March 1966 & 11 & $\begin{array}{l}\text { Restored excise tax rates on transportation equpment } \\
\text { and telephone service to rates in effect prior to Janu } \\
\text { ary } 1966 \text {, Introduced graduated withholding on personal } \\
\text { tax collections }\end{array}$ \\
\hline Temporary suspension of & November 1966 & ж & As of october 10,1966, temporatly suspended $7 \mathrm{per}$ \\
\hline Restoration of Investment & June 1967 & 17 & As of March 10 , 1967 , restored investment tax credit \\
\hline Revenue and Expenditure & June 1968 & 10.2 & $\begin{array}{l}\text { Levied } 10 \text { percent surtax on personal noome taxes } \\
\text { Jafective April } 1,1968 \text {, and on coiporate taxes effective } \\
\text { rates on automobiles and telephone service. }\end{array}$ \\
\hline Extension of Surtax. & Algust 1969 & 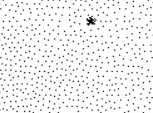 & $\begin{array}{l}\text { Extended } 10 \text { percent surtax on personal and corporate } \\
\text { incomes, previously, scheduled to expire on June } 30 \text {, } \\
1069 \text {, to December } 31,1969,\end{array}$ \\
\hline Tax peform Act of 1969 & December 1969 & 2,5 & 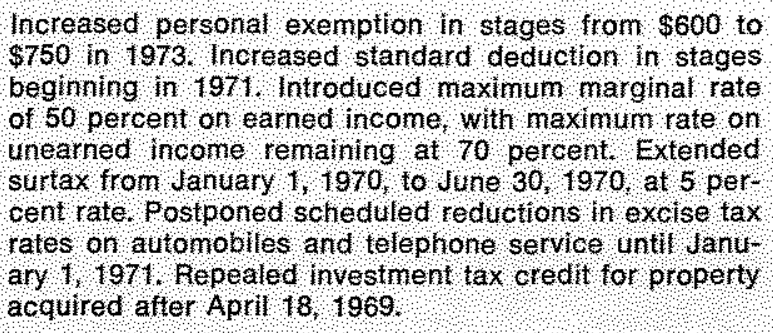 \\
\hline
\end{tabular}


Table 1 (Continued)

\begin{tabular}{ccc}
\hline & $\begin{array}{c}\text { Revenue } \\
\text { effect } \\
\text { (billions } \\
\text { of dollars) }\end{array}$ & Nate \\
enacted & Nature of action & \\
\hline
\end{tabular}

$\begin{array}{ccc}\begin{array}{c}\text { Excise, Estate and Gift Tax } \\ \text { Adjustment Act of } 1970\end{array} & \text { December } 1970 & \text { Extended excise tax rates on automobiles and tele- } \\ \text { phone service until January 1972. Sped up collections } \\ \text { of oetate and gift taxos. }\end{array}$

\author{
Treasury's Asset Depreciation June 1971 \\ Range Guidelines
}

Revenue Act of 1971

Tax Reduction Act of 1975

March 1975

Revenue Adjustment Act of 1975

Tax Reform Act of 1976

Tax Reruntion \& Simplification Act of 1977

Revenue Act of 1978

Energy Tax Act of 1978

Crude Oil Windfall Profits

Tax Act of 1980

Omnibus Reconciliation Act of 1980

May 1977
December $1971 \quad \$-8.0$

"Indicates either that (1) the action was minimal in its effect, (2) such a calculation was not appropriate because the action extended provisions of expiring legislation, or (3) official estimates were not available.

SOURCES: Joseph A. Pechman, Federal Tax Policy, 3rd ed. (The Brookings Institution, 1977); Federal Reserte Bulletin
December 1975

October 1976

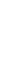
maximum of $\$ 200$ for individuals. Provided tax cuts retroactive to January 1975 for both individuals and corporations. For individuals it was in the form of increased standard deductions, $\$ 30$ exemption credit and an earned income credit for low-income families. Reduced corporate income tax and increased investment surtax exemption. Increased investment tax credit to 10 percent. Extended corporate rate reductions enacted in Tax Reduction Act of 1975. Reduced individual taxes in order to maintain withholding rates that applied during last eight months of 1975.

1.6 Provided extensive redrafting of tax laws. Restricted use of tax shelter investments and made changes in taxing of gifts and estates. Increased taxes on very wealthy. Continued tax cuts passed in 1975.

Fxtended for one year the temporary provisions of the Tax Reform Act of 1976, including the general tax credit, the earned income credit and corporate tax reductions. Provided a temporary jobs tax credit. Replaced former standard deduction with amount equal to $\$ 3,200$ for joint returns, $\$ 2,200$ for single persons and $\$ 1,600$ for married persons filing separately.

21.3 Reduced taxes for individuals and businesses. Contained some elements of tax reform. Extended several temporary provisions of Tax Reduction and Simplification Act of 1977.

-0.8 Introduced taxes and credits for purposes of reducing country's reliance on foreign energy supplies.

13.0 Levied windfall profits tax on domestic producers of crude oil and provided several income tax credits to encourage production and conservation of energy. Provided partial exclusion of interest and dividend income from income tax.

December 1980

November 1978
-22.8 Provided for 10 percent rebate on 1974 taxes up to
3.4 Imposed restrictions on use of mortgage subsidy bonds plus other miscellaneous tax changes.

\footnotetext{
(September 1978 and June 1973), Annual Report of the Secretary of Treasury, and The Budget of the United States Government.
}

Stutes Governtrent. 
Table 2

Effects of Social Security Legislation

\begin{tabular}{|c|c|c|c|c|}
\hline Year & $\begin{array}{c}\text { Taxable } \\
\text { wage base } \\
\text { (dollars) }\end{array}$ & $\begin{array}{l}\text { Combined } \\
\text { tax rate } \\
\text { (percent) }\end{array}$ & $\begin{array}{l}\text { Maximum tax } \\
\text { for employee } \\
\text { (dollars) }\end{array}$ & $\begin{array}{c}\text { Effect on } \\
\text { federal revenues } \\
\text { (billions of dollars) }\end{array}$ \\
\hline 1955 & $\$ 4,200$ & $4.0 \%$ & $\$ 84$ & $\$ 0.6$ \\
\hline 1066 & 4,200 & 4.0 & 84 & $*$ \\
\hline 1957 & 4,200 & 4.5 & 95 & 1.1 \\
\hline 1958 & 4,200 & 4.5 & 95 & * \\
\hline 1959 & 4,800 & 5.0 & 120 & 1.5 \\
\hline 1960 & 4,800 & 6.0 & 144 & 1.9 \\
\hline 1961 & 4,800 & 6.0 & 144 & $*$ \\
\hline 1962 & 4,800 & 6.25 & 150 & 0.5 \\
\hline 1963 & 4,800 & 7.25 & 174 & 2.1 \\
\hline 1964 & 4,800 & 7.25 & 174 & * \\
\hline 1965 & $4,8 \cap 0$ & 7.25 & 174 & * \\
\hline 1966 & 6,600 & 8.4 & 277 & 6.2 \\
\hline 1967 & 6,600 & 8.8 & 290 & 1.2 \\
\hline 1968 & 7,800 & 8.8 & 342 & 2.1 \\
\hline 1969 & 7,800 & 9.6 & 374 & 3.0 \\
\hline 1970 & 7,800 & 9.6 & 374 & $\star$ \\
\hline 1971 & 7,800 & 10.4 & 406 & 3.2 \\
\hline 1972 & 9,000 & 10.4 & 468 & 2.9 \\
\hline 1973 & 10,800 & 11.7 & 632 & 10.8 \\
\hline 1974 & 13,200 & 11.7 & 722 & 3.9 \\
\hline 1975 & 14,100 & 11.7 & 825 & 1.4 \\
\hline 1976 & 15,300 & 11.7 & 895 & 2.1 \\
\hline 1977 & 16,500 & 11.7 & 965 & 2.1 \\
\hline 1978 & 17,700 & 12.1 & 1,071 & 5.6 \\
\hline 1979 & 22,900 & 12.26 & 1,404 & 9.5 \\
\hline 1980 & 25,900 & 12.26 & 1,588 & 3.6 \\
\hline 1981 & 29,700 & 13.30 & 1,975 & 16.6 \\
\hline
\end{tabular}

${ }^{*}$ No change in legislation.

SOURCE: 1980 Statistical Abstract, except for effect in 1955 and 1957 estimated by Federal Reserve Bank of St. Louis.

Since 1961, however, tax legislation has been frequent and oftentimes large in magnitude. Even so, apart from the effect of legislation enacted during the Vietnam War, total tax revenues as a percent of GNP changed little from 1961 to 1976. Since then, however, this trend appears to have been broken.

An examination of chart 1 indicatcs that since 1976 , total receipts have been rising faster than GNP. For the entire $1955-80$ period, receipts as a percentage of GNP range from 16.8 percent in 1958 to 20.6 percent in 1969. Since 1976, even though new legislation has generally reduced tax rates, the tax base has grown more rapidly than GNP; consequently, receipts as a percent of GNP have trended upward.

Chart 2 summarizes each of the major taxes as a percent of total receipts. Throughout the entire 195580 period, the individual income tax was the major source of revenue to the federal government, providing between 41 percent and 47 percent of the total. As a proportion of total revenue, however, individual income taxes have varied considerably over the years. There are two reasons for this: One, the proceeds of 


\section{Table 3}

\section{Administration Economic Assumptions}

\begin{tabular}{|c|c|c|c|c|c|c|c|}
\hline & \multicolumn{7}{|c|}{ Calendar Years } \\
\hline & \multirow{2}{*}{$\begin{array}{l}\text { Actual } \\
1980\end{array}$} & \multicolumn{6}{|c|}{ Estimate } \\
\hline & & 1981 & 1982 & 1983 & 1984 & 1985 & 1986 \\
\hline \multicolumn{8}{|l|}{ Gross national product } \\
\hline (4) current dollars (percent change) & $8.9 \%$ & $11 \%$ & $128 \%$ & $12.4 \%$ & $10.8 \%$ & $98 \%$ & $93 \%$ \\
\hline Constant 1972 dollars (percent change) & -0.1 & 11 & 4.2 & 5.0 & $4 \%$ & 42 & 42 \\
\hline Deliator (percent change) & 90 & 9.9 & 8.3 & 70 & 6.0 & 6.4 & 4.9 \\
\hline Unemployment rate (percent) & 12 & 78 & 72 & 6.6 & 6.4 & 6.0 & 6.6 \\
\hline \multicolumn{8}{|l|}{ Proxies for tax bases } \\
\hline Personal hicome (percent change) & 111 & 25 & 11.5 & 115 & 9.9 & 9.3 & 9.2 \\
\hline Wages and salaries (percent change) & 8,7 & 107 & 120 & 11.2 & 9.8 & 01 & 8.8 \\
\hline Corporate proftis (percent change) & 5 & 0,4 & 161 & 16.0 & 12.6 & 112 & 115 \\
\hline
\end{tabular}

SOURCE, Executive Offee of the President and Office of Mallagenent and Budget, Fiscal Year 1982 Budget heorions (Mareh 1981)

this tax are highly sensitive to movements in economic activity. Two, most of the major tax bills enacted in the last 25 years contained provisions that directly affected this particular source of revenue.

Aside from the individual ineome tax, the remainder of the federal tax structure has changed significantly since 1955. Social insurance contributions, for example, replaced corporate income taxes as the second most important source of revenue after 1966. The decline in the proportion of corporate income taxes to total receipts primarily reflects the downward trend of corporate profits relative to GNP. In addition, however, the effective tax rate for corporate income has been reduced several times since 1955 .

The steady rise of social insurance contributions as a percent of total revenues from 1955 to 1975 is the result of frequent increases in the tax rate and the expansion of the tax base (table 2). Since 1975, however, social insurance contributions have stabilized at about 31 percent of total revenues despite anmual increases in the taxable wage base.

Excise taxes have become increasingly less important as a source of federal revenue for two reasons: First, major reductions in excise taxes were legislated in 1965 and 1971. Second, revenues from this tax do not generally rise with inflation since they are usually expressed as an amount per physical unit (for example, the federal excise tax on gasoline is 4 cents per gallon).
Finally, other taxes, which include ctustoms duties, estate and gift taxes, and miscellaneous receipts, have been rising in relative importance, with the average rate of increase for the $1955-80$ period exceeded only by social insurance contributions.

\section{PROJECTIONS OF FEDERAL REVENUES: 1981.86}

The administration has submitted a set of proposals that affects the federal revenue system. Viewed against the trends of the last 25 years, how would these proposals affect the total and the composition of federal tax revenues?

\section{Economic Assumptions}

As noted above, changes in the total and the composition of federal revenues occur even without tax legislation. Consequently, projections of future revenue depend, in part, on the nature of one's economic assumptions. The administration's economic assumptions are summarized in table 3 .

The key assumption underlying the projected growth of federal revenues is the growth in nominal GNP. The administration has projected a relatively rapid 11 percent average rate of growth in nominal GNP for the 1980-86 period. Given the historical relationship between money and GNP, this GNP 
growth path implies that M1B will have to increase at an average 8 percent rate over this period. 6

The administration does not specify its assumptions about the relevant tax bases for particular taxes. Certain indicators, however, serve as proxies. For example, personal income is a proxy for the tax base pertinent to individual income taxes and, with consumption dependent on personal income, it serves the same purpose for excise taxes. Corporate profits before taxes provide a tax base proxy for corporate income taxes. Wages and salaries are a proxy as a tax base for social insurance contributions. The projected growth of each of these tax bases depends primarily on the assumed growth of GNP.

Although economic assumptions relating to prices and output are important in and of themselves, they are not so critical for tax projections. Nominal GNP, regardless of the way it is divided between price and output, is the most important determinant of revenue. ${ }^{7}$

\section{Proposed Legislation}

The administration's economic program centers on a reduction of individual income tax rates and depreciation reform. In addition, it proposes to increase aviation-user taxes and user fees for barge operators.

Individual income taxes - Proposals that affect individual income taxes include reducing marginal tax rates by 10 percent each year for the next three years, beginning July 1, 1981. Tax rates would be reduced relative to 1980 by 5 percent for calendar 1981, 15 percent for calendar 1982, 25 percent for calendar 1983 , and 30 percent for calendar 1984. Marginal rates would be reduced from their present range of 14-70 percent to $10-50$ percent as of January 1,1984 . In addition, to the extent that depreciation reform applies to unincorporated businesses, individual income taxes would be further reduced through a reduction in the taxable income of proprietors and partnerships.

Comprate income taxes - The proposed "accelerated cost recovery system" enables corporations to write-off capital expenditures faster, under simplified and standardized rules, and liberalizes the laws relating to the investment tax credit. The program centers

"For further discussion of the consistency of the administration's forecast of GNP and its monetary policy assumptions, see Congressional Budget Office, An Analysis of President Reagan's Budget Revisions for Fiscal Year 1982, Staff Working Paper (March 1981), pp. 9-11.

TSee Congressional Budget Office, A Review of the Accuract of Treasury Revenue Forecasts, 1963-1978, Staft Working Paper (February 1981). on a "10-5-3" year classification of property. Three-year property consists of autos and light trucks plus machinery and equipment used in research and development. Fivenyear property consists of other machinery and equipment. Ten-year property includes factory buildings, retail stores, warehouses and some public utility property.

Social insurance contributions - The only proposal affecting social insurance contributions is an increase in railroad retirement payroll taxes. Otherwise, such contributions are scheduled to increase through 1984 under existing legislation. ${ }^{8}$

Excise taxes - Increased charges are proposed for aviation users and barge operators. These charges are intended to recover most of the costs associated with the movement of air traffic and the operation and construction of new waterway facilities.

\section{Projected Trends}

The economic assumptions and the proposed legislation provide the basis for revenue projections. Since the proposed legislation takes the form of either changed tax rates or new taxes, revenue trends in the absence of such legislation provide a useful basis for analyzing the impact of the proposed changes. Revenue projections based on existing legislation are called "current services estimates,"

Current services basis - Charts 1 and 2 show revenues projected on a current services basis as a perm cent of GNP, and the component taxes as a percent of total receipts." The nominal GNP used for these calculations are the administration's estimates as of March 1981. Although the split of GNP between prices and output would probably be different if, in fact, no tax changes were legislated, there is little reason to think that nominal GNP would be any different. ${ }^{10}$

8The existing legislative schedule for social security taxes includes the following:

$\begin{array}{ccc}\begin{array}{c}\text { Calendar } \\ \text { year }\end{array} & \text { Wage base } & \begin{array}{c}\text { Combined } \\ \text { tax rate }\end{array} \\ 1981 & \$ 29,700 & 13.3 \% \\ 1982 & 32,100 & 13.4 \\ 1983 & 35,400 & 13.4 \\ 1984 & 38,700 & 13.4\end{array}$

9Current services estimates are derived from Fiscal Year 1982 Budget Revisions, pp. 122-23.

10This, of course, is a "monetarist" interpretation. For evidence indicating that nominal GNP depends on the growth of money stock, see Keith M. Carlson, "Money, Inflation, and Economic Growth: Some Updated Reduced Form Results and Their Implications," this Review (April 1980), pp. 13-19. 
Federal Budget Receipts as a Percent of GNP :

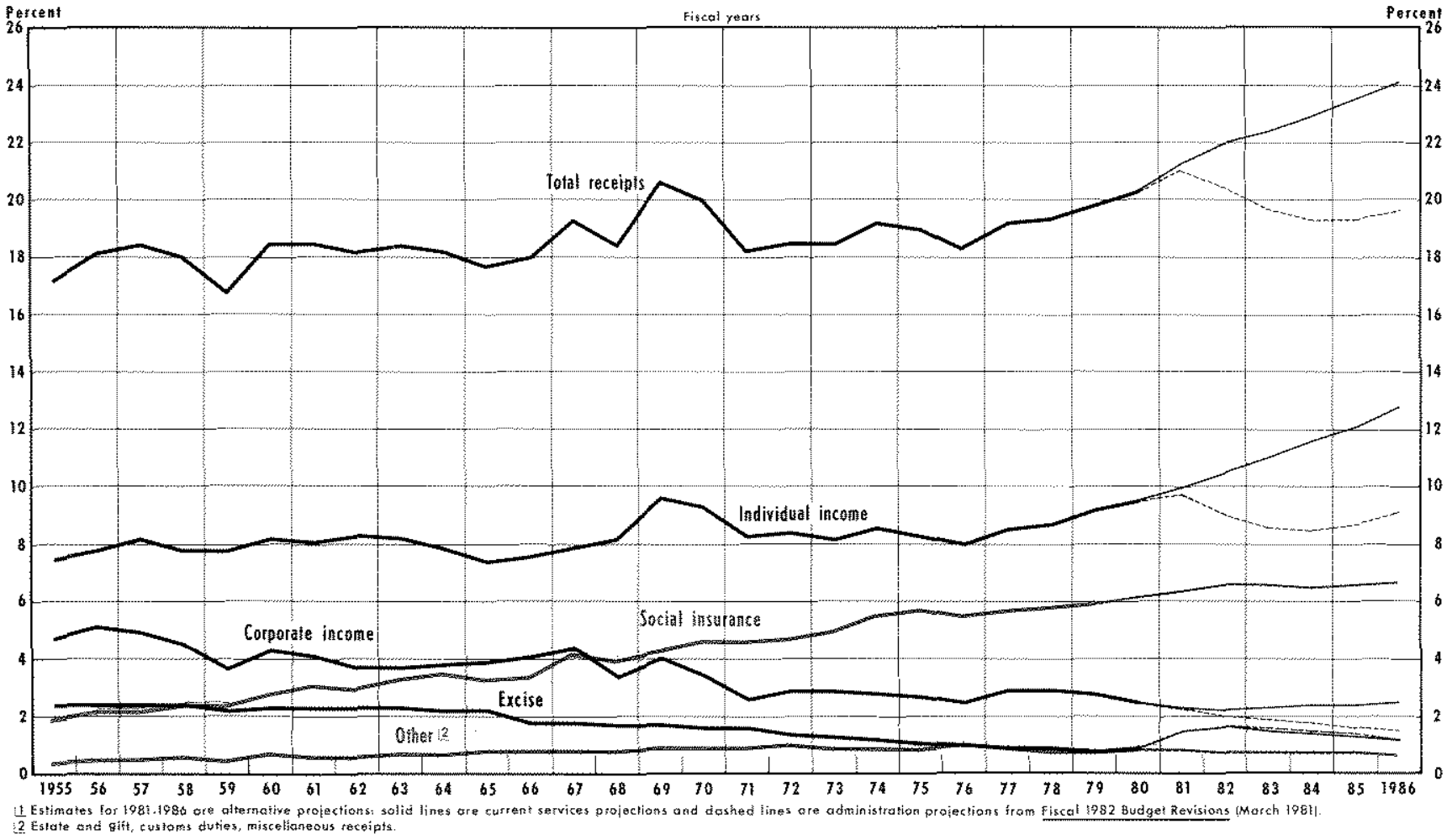

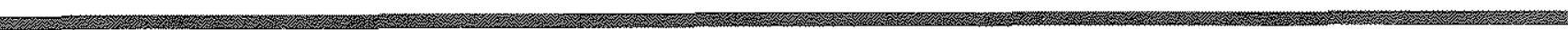

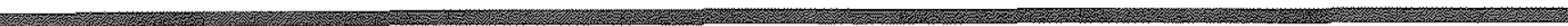

Federal Budget Receipts as a Percent of Total Receipts

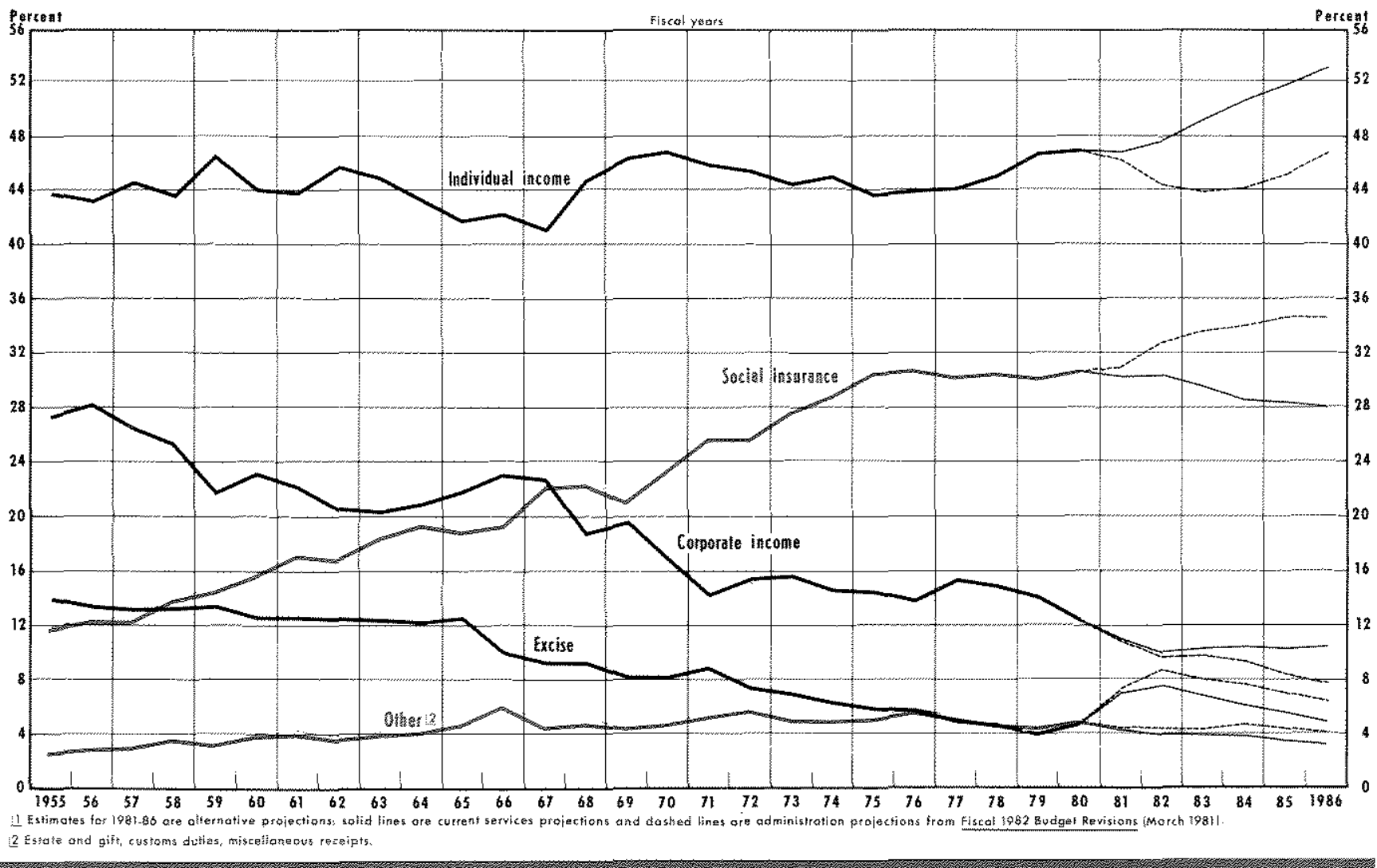


Table 4

\section{Marginal and Average Tax Rates for Individual Income Tax (percent)}

Calendar
year
Marg nal

As applied to adjusted gross income

SOURCES Jont Comnittee on Taxation and Federal Reseve Bank of St. Lours.

Chart 1 shows that, with no changes in tax legisla tion, total receipts would rise to 24.1 percent of GNP in 1986, compared with 20.3 percent in 1980 . The rise would largely be a result of the individual income tax, which would rise from 9.5 percent of GNP in 1980 to 12.8 percent in 1986 . When viewed in terms of marginal rates as applied to adjusted income, the rise is even more dramatic (see table 4). Because existing legislation provides for increases in both the wage base and tax rate, social insurance contributions would also rise relative to GNP, from 6.3 percent in 1980 to 6.8 percent in 1986 . The remaining taxes would change little relative to GNP over the same period.

Chart 2 shows the distribution of taxes on a current services basis. With no legislation, individual income taxes would rise to 53.0 percent of total receipts by 1986, up from 46.9 percent in 1980. Social insurance contributions would drop to 28.2 percent of total receipts in 1986 from 30.9 percent in 1980 . Corporate income taxes would continue to decline as a proportion of the total, to 10.4 percent compared with 12.4 percent in 1980. Excise taxes would rise early in the period because of the windfall profits tax, but would then fall back, showing little change relative to total receipts from 1980 to 1986 .

Administration projections - The revenue impact of the administration's proposal is also shown in charts 1 and 2. Relative to GNP, total receipts would decline from 20.3 percent in 1980 to 19.6 percent in 1986 , a decline that occurs because the tax cut primarily affects individual and corporate income taxes. Although individual income taxes relative to GNP decline only from 9.5 percent in 1980 to 9.1 percent in 1986, the tax cut is large relative to the current services estimate. Furthermore, the rapid rise in marginal rates would be arrested (table 4). The decline in corporate income taxes is somewhat greater, 1.5 percent of GNP in 1986 compared with 2.5 percent in 1980. Social insurance contributions differ little from current services estimates because the proposed legislation is not directed at these taxes. The remaining taxes are projected to keep pace with GNP, that is, their proportions change little from 1980 to 1986.

Chart 2 summarizes the distribution of total receipts among the components. Although varying during the projection period, individual income taxes in 1986 would be about the same proportion of the total as they were in 1980 - almost 47 percent. Social insurance contributions on the other hand, would rise from 30.9 percent of total receipts in 1980 to 34.8 percent in 1986. Corporate income taxes continue their fall from the $1955-80$ period to 7.7 percent of total receipts in 1986. Excise taxes, after rising relative to the total in 1981 and 1982, end up somewhat higher in 1986 than in 1980. Other taxes and revenues are essentially unchanged as a percent of total receipts. 


\section{SUMMAPI}

This article summarizes trends in federal revenues over the past 25 years, examining the potential impact of proposed legislation on these trends for coming years. Only tax receipts are considered explicitly; funds raised by borrowing and money creation are ignored. Furthermore, no attempt is made to evaluate the program in terms of conventional criteria such as impact on economic growth, resource allocation, distribution of income or economic stabilization. Nevertheless, the simple description of developing trends is a starting point for a more complete economic analysis.

Examination of revenue trends for the period 195580 indicates that, for most of the period, total receipts essentially kept pace with nominal GNP, though they have accelerated recently. Even so, 1980 total receipts as a percent of GNP were still below the proportion reached in 1969 when a surcharge was added to individual and corporate income taxes during the Vietnam War. Though total receipts remained relatively stable, its composition changed dramatically over the 1955-80 period. Individual income taxes as a percent of total receipts fluctuated within a fairly narrow band, but social insurance contributions rose from 11.9 percent of the total in 1955 to 30.9 percent in
1980. Both corporate income taxes and excise taxes declined throughout the period.

The administration has proposed legislation that would significantly affect these trends. The relevant comparison against which to measure the impact of these proposals is the current service estimates, that is, projections based on the existing tax structure. On a current services basis, total receipts would rise sharply to 24.1 percent of GNP in 1986. The effect of the proposed legislation, which affects mainly individual and corporate income taxes, would be to reduce the rise of total receipts relative to GNP. However, the proposed tax cuts would be insufficient to lower the percentage of total receipts to GNP to its $1955-80$ average of 18.6 percent.

With respect to the relationship of specific taxes to total receipts, the legislation appears roughly to keep past trends intact. In other words, individual income taxes would rise slightly relative to total receipts, while social insurance contributions would continue the rising trend established in the $1955-80$ period. Corporate income taxes would continue downward, but excise taxes would reverse their 1955-80 downward trend and rise in the $1980-86$ period.

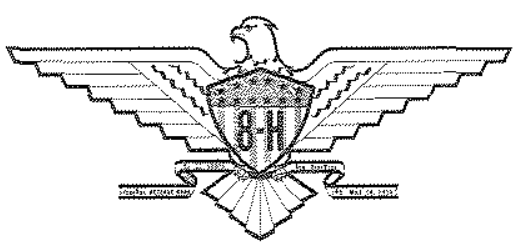

